Balantekin, Y. (2021). İlkokul düzeyinde Türkçe dersinde yaşanan sorunlara yönelik çalışmaların analizi: Bir metasentez çalışması. Ana Dili Eğitimi Dergisi, 9(1), 242-261.

Ana Dili Eğitimi Dergisi
Journal of Mother Tongue Education
www.anadiliegitimi.com
Geliş/Received: 08.09.2020 Kabul/Accepted:27.01.2021
Araştırma Makalesi / Research Paper

\title{
İlkokul Düzeyinde Türkçe Dersinde Yaşanan Sorunlara Yönelik Çalışmaların Analizi: Bir Meta-Sentez Çalışması
}

\author{
Yakup BALANTEKIN*
}

\begin{abstract}
Öz
Bu araştırmada ilkokul düzeyinde Türkçe derslerinde yaşanan sorunları belirlemeyi amaçlayan çalışmalardan hareketle dinleme, konuşma, okuma ve yazma becerilerinde yaşanan sorunlar ortaya koymak amaçlanmıştır. Araştırma meta-sentez yöntemiyle yürütülmüştür. Araştırma kapsamına alınmak için gerekli koşulları sağlayan toplam 17 çalışma ile araştırma yürütülmüştür. Araştırma sonunda dinleme becerisi ile ilgili yeteri kadar çalışma olmadığı, dinleme becerisinin gelişiminde sorunların daha çok öğrenci kaynakıı nedenler olduğu, öğrenci dikkat ve motivasyon eksikliği ile öğrencilerin söz varlığı yetersizliğinin dinleme becerisinin gelişiminde sorun olduğu; konuşma becerisinde yaşanan sorunların çoğunlukla öğrencilerin söz varlığı yetersizliğinden kaynaklandığı; okuma becerisi ile ilgili öğrencilerin doğru ve akıcı okumada sorun yaşadıkları, öğrencilerin heceleyerek okudukları, okuduklarını anlamada sorun yaşadıkları; en çok yazma becerisi ile ilgili çalışma olduğu, öğrencilerin noktalama işaretleri kullanma, yazım kurallarını uygulama ve yazmanın fiziksel boyutu ile ilgili sorunlar yaşadıkları belirlenmiştir. Öğrencilerin söz varlığını geliştirmeyi amaçlayan araştırmalar yapılması, araştırmaların belli dil becerilerinde yoğunlaşmayıp ihtiyaca odaklı olabilmesi için önlemler alınması önerilmiştir.
\end{abstract}

Anahtar Kelimeler: Dinleme, konuşma, okuma, yazma

\section{An Analysis of Studies on Problems Encountered in Turkish Lessons at Primary School Level: A Meta-Synthesis Study}

\begin{abstract}
This study aimed to examine the problems encountered in listening, speaking, reading, and writing skills based on studies aiming to identify the problems encountered in Turkish lessons at primary school level. The meta-synthesis method was applied in this study. 17 studies that provided the necessary conditions were included in the study. As a result of the study, it was determined that listening skills were scarcely examined, that problems in listening skills mostly stemmed from student-related reasons, and that lack of student attention and motivation and also lack of vocabulary of students were the problems in the development of listening skills. Problems in speaking skills were mostly caused by students' lack of vocabulary. Regarding reading skills, it was determined that students had problems in reading accurately and fluently, that students read by spelling out words, and that they had problems in reading comprehension. It was determined that writing skills were examined the most; students had problems with using punctuation marks, applying spelling rules, and the physical dimension of writing. It is recommended that research aimed at improving students' vocabulary is conducted and that measures should be taken so that research does not focus on specific language skills but rather focuses on needs.
\end{abstract}

Keywords: Listening, speaking, reading, writing

*Dr. Öğr. Üyesi, Uludağ Üniversitesi, Eğitim Fakültesi, Temel Eğitim Bölümü, Bursa, yakupbalan@gmail.com, ORCID: orcid.org/0000-0002-8684-3598 


\section{Giriş}

Bireyin ve toplumun gelişmesinde bilgiyi üretme ve bilgiye sahip olma önemli bir yer tutmaktadır. Özellikle insanoğlunun varlığını korumak adına geleceğini güven altına alma isteği insanları hem toplumsal hayatı ve kurumları hem de bireysel hayatı bilgi üzerine inşa etmeye zorlamaktadır. Toplumsal kurumlar içerisinde önemli bir yere sahip olan eğitim kurumları bireylerin bilgiyi ve bilgiye ulaşma yollarını edinmesinin sorumluluğunu üstlenmiştir. Bu nedenle bireylerin eğitim öğretim sistemi içerisinde bulunma süresinin artırılması gelişmişliğin bir göstergesi olarak kabul edilmektedir.

Dünyada ve Türkiye'de öğrencilerin eğitim öğretim hayatına başladıkları temel eğitim döneminde öğrencilere ilk olarak öğrenmenin temeli ve insan zihninin sınırsız bir gücü olan dil (Güneş, 2019) eğitiminin bileşenlerini oluşturan dinleme, konuşma, okuma ve yazma eğitimi verilmektedir (Örs, 2019). Ana dili eğitimi bireyin toplumsal ve sosyal gelişimini desteklerken aynı zamanda bilgiyi elde etmenin ve aktarmanın en kestirme yolu olan okuma ve yazma becerisinin gelişimini de sağlamaktadır (Altun ve Batmaz, 2018; Özbay ve Melanlıoğlu, 2012; Şahin, 2012).

Ana dili eğitiminin temeli olan dinleme, konuşma, okuma ve yazma becerilerinin gelişimi Türkçe dersi kapsamında yürütülmektedir (Belet ve Yaşar, 2007; Kurudayıoğlu ve Çetin, 2015). İnsanların yaşamlarını düzenleyen, onları bir arada tutarak onları bir millet yapan, düşünmeyi, anlamayı ve bunları ifade etmeyi sağlayan dil becerilerinin öğretiminin gerçekleştirildiği Türkçe dersi önemini buradan almaktadır (Girmen, Kaya ve Bayrak, 2010). Ayrıca Türkçe dersinde kazanılan becerilerin öğrencilerin diğer derslerdeki başarısını etkilemesi bu önemi daha da artırmaktadır (Akın ve Çeçen, 2015).

Ana dili eğitiminde dilin özünü oluşturan yapıların öneminin farkına varılması (Kuzu, 2004) ve sözcük olarak ifade edilen göstergelerin (Cemiloğlu, 2009) anlam ve kullanımlarının öğretiminin amaçlanması dil eğitimi sürecinde öğrencilerin aktif olmasını gerektirmektedir (Güneş, 2013). Bu nedenle Milli Eğitim Bakanlığı (2019: 8) Türkçe Dersi Öğretim Programı́nın yaklaşımını “Öğrencilerin öğrenme öğretme sürecine aktif katılımı sağlanmalı ve öğrenciler kendi öğrenmelerinin sorumluluğunu almaları konusunda teşvik edilmelidir." şeklinde ifade etmiştir. Türkçe öğretimi ile hedeflenen dinleme, konuşma, okuma ve yazma becerileri çeşitli türdeki metinler ve metinlerle tümleşik bir etkinlik anlayışıyla öğrencilere kazandırılmaktadır (Çer, 2016). Bu öğretim biçiminin tercih edilmesinin nedeni bireylerin yaşamları boyunca karşılaştıkları metinlerde sunulan bilgileri anlamaya çalışmalarından kaynaklanmaktadır (Temizyürek ve Delican, 2016).

Dinleme becerisi birey daha dünyaya gelmeden anne karnında ortaya çıkan ve gelişen bir beceridir (Özbay ve Çetin, 2011). Bunun yanı sıra dinleme, bireyin yaşamda en çok kullandığı beceri olup konuşma, okuma ve yazma becerilerinin temelini oluşturmaktır (Emiroğlu ve Pınar, 2013). Dinleme, dil becerileri arasında belirginliği en az olan beceri olduğu için öğrenilmesi en zor olan beceri olarak algılanmaktadır (Vandergrift, 2004). Özbay ve Melanlıoğlu'na (2012) göre dinleme fark edilmeden gelişen bir beceri olduğu için okullarda dinleme eğitimine yeterince yer verilmemektedir. Öğretmenlerin bir kısmı öğrencilerin bu beceriyi okula başlamadan önce öğrendiklerini varsaydığı için derslerde dinleme eğimini inmal etmektedirler (Akyol, 2019). Spataro ve Bloch (2018) dinlemenin etkin olabilmesi için bireyin konuşmacıya sorgulama, yansıtma, saygı ve empati yoluyla tam dikkat vermesini ancak bu şekilde dinlemenin basit bir işitme olayından farklı olabileceğini vurgulamaktadır.

Zihinsel bir etkinlik olan konuşma (Demir, 2010) bireyin sosyal ilişkilerini devam ettirebilmek için en fazla kullandığı dil becerisidir (Bayburtlu, 2019). İnsan doğuştan konuşabilme yeteneği ile dünyaya gelmekte, ailenin çocukla kurduğu rastgele iletişim sayesinde bu beceri gelişmekte ancak konuşma becerisinin etkin bir biçimde kullanılması okulda verilen eğitim ile mümkün olmaktadır (Şahbaz ve Çekici, 2012; Uçgun, 2007). Budinski ve Lujić (2018) konuşma becerisinin düzenli olarak gelişimi için biyolojik ve çevresel faktörler arasında dinamik bir etkileşim olması gerektiğini vurgulamaktadır. Konuşma becerisi gelişmiş bireylerin hayatta daha başarılı olmaları (Bağcı Ayrancı, 2016) nedeniyle konuşma eğitimi sonunda bireyler duygularını, düşüncelerini sözlü olarak doğru bir biçimde aktarmak için uygun sözcük ve cümleleri seçerek doğru ve düzgün bir söyleyiş biçimini kullanabilmelidirler (Temizyürek, Erdem ve Temizkan, 2017).

Bireylerin ilkokulda kazandığı ve yaşam boyu kullandığı okuma becerisi (Seçkin Yılmaz ve Baydık, 2020) onların öğrenim sürecini ve sosyal yaşamını etkileyen bir beceridir (Kim, Petscher, 
Wanzek ve Otaiba, 2018). Okuma bireyin karşılaştığı sorunları çözebilmesini, kendisi için gerekli olan bilgileri ayırt edebilmesini ve bu bilgileri gereken durumlarda kullanabilmesini sağlamaktadır (Bozkurt, 2016). Kuşdemir ve Katrancı (2016) okuma eyleminde amacın anlama ulaşmak ve anlamlar oluşturmak olduğunu belirtmiştir. Okuduğunu anlama becerisi karmaşık bir süreç sonunda gelişmektedir (Landi, 2010) Bu nedenle okuma hızı ve metnin doğru okunmasını kapsayan akıcı okuma becerisi okuma eğitiminde hedeflenmelidir (Erden ve Çelik 2019). Sönmez (2020) akıcı okuma için bireyin sözcük tanıma ve anlama gücünün geliştirilmesi gerektiğini ve bu amaçla yapılacak okuma pratiklerinin etkili olacağını ifade etmektedir. Bireyin söz varlığının geliş̧miş olması onun okuma becerisinin gelişimini desteklemektedir (Braze ve ark., 2016). Ayrıca söz varlığının gelişmiş olması bireyin yeni sözleri daha hızlı ve kolay öğrenmesini de sağlamaktadır (Geva, Galili, Katzir ve Shany, 2017). Söz varlı̆ı̆ın kendi kendini ve akıcı okuma becerisini geliştirmesi ve akıcı okumanın anlamayı kolaylaştırması bir arada düşünüldüğünde okuma gelişimi için söz varlığı gelişiminin önemi daha da anlaşılır olmaktadır.

Bireyin öğrenme sürecinde ve çevresiyle iletişim kurmasında önemli bir yere sahip olan yazmada (Duran ve Özdil, 2020; İş̧i, Susar Kırmızı ve Akkaya, 2020) amaç çeşitli sembol ve işaretleri kullanarak bireyin kendini doğru bir biçimde ifade edebilmesidir (Kim, Park ve Park, 2015; Yıldırım ve Ateş, 2010). Bu nedenle bireylerin yazma becerisinin geliştirilmesi bütün dil eğitimlerinin temel amacını oluşturmaktadır (Hamzadayı, 2019). Yazma bilgiden çok beceri eksenli olduğundan (Yıldız, Yıldırım ve Ateş, 2009) bireylerin okunaklı ve akıcı yazabilmesi için erken dönemde yazma becerisini geliştirmeye yönelik çalışmalar yapıımalıdır (Feng, Lindner, Ji ve Joshi, 2019). Yazma eğitimine yönelik yapılan çalışmaların başarıya ulaşmasında içerik ve biçim açısından bireyin yakın çevresinden hareket edilmesi onun daha derin anlamlara ulaşmasını sağlayacaktır (Spycher, Austin ve Fabian, 2018). Yazma becerisinde amaçlanan okunaklılık, akıcı ve doğru yazma birçok unsurdan etkilenmektedir. Bu amaçlara ulaşmak için bireylere verilen yazma eğitiminin yeterli ve düzenli bir biçimde olması gerekmektedir (Yıldız vd., 2009). Yazma eğitiminde öğrencilerin öncelikli olarak biçimsel açıdan harfleri doğru yazabilmelerinin sağlanması onların yazı yazarken bilişsel açıdan içeriğe odaklanmalarını sağlayacaktır (Semeraro, Coppola, Cassibba ve Lucangeli, 2019). Ayrıca doğru ve anlamlı yazmayı sağlayan yazım kurallarını kullanma becerisi öğrencilerin yazma başarısı ve motivasyonunu etkilediği için yazma eğitimi sırasında göz ardı edilmemelidir (Puliatte ve Ehri, 2018).

Bu araştırmada, ilkokul düzeyinde Türkçe derslerinde yaşanan sorunları belirlemeyi amaçlayan araştırma bulgularının yeniden yorumlanıp karşılaştırılarak değerlendirilmesi amaçlanmıştır. Bu yaklaşımla farklı yerlerde ve farklı örneklem gruplarıyla aynı amaca yönelik olarak yapılan çalışmaların bulgularının bütüncül yaklaşımla sunulması sağlanacaktır. Böylece sınıf öğretmenleri Türkçe dersinde yaşanan sorunları geniş bir perspektiften görme imkânı bulacaktır. Araştırmanın sadece ilkokul düzeyinde Türkçe dersinde yaşanan sorunlara odaklanması aracılığıyla Türkçe öğretimi alanında ilkokul öğrencilerine yönelik çalışmaların diğer öğretim kademesinde öğrenim gören öğrencilerden ayrı olarak yapılandırılması gerektiğine dikkat çekmek hedeflenmektedir. Ayrıca konu ile ilgili yapılan çalışmaların yoğunlaştığı ve seyrekleştiği alanları göstererek konu ile ilgilenen araştırmacılara da yapmayı planladıkları çalışmalar hakkında fikir vermek de araştırmanın farklı bir yönüdür. Dinçer (2018) herhangi bir konuda araştırma yapmak isteyen araştırmacılara meta-analiz, meta-sentez ve betimsel analiz gibi yöntemlerinden birini kullanıp bu konudaki tartışmalı ya da değinilmemiş noktaları tespit ederek araştırmasını buna göre planlamasını önermektedir. Yukarıda bahsedildiği gibi araştırmacılar mevcut araştırma konusunun farklı boyutlarını görme fırsatı bulacaklardır. Bahsedilen bu amaçlar doğrultusunda aşağıdaki sorulara yanıtlar aranmıştır.

(I) ilkokul düzeyinde Türkçe dersi dinleme becerisi alanında yaşanan sorunlar nelerdir?

(II) İlkokul düzeyinde Türkçe dersi konuşma becerisi alanında yaşanan sorunlar nelerdir?

(III) IIlkokul düzeyinde Türkçe dersi okuma becerisi alanında yaşanan sorunlar nelerdir?

(IV) illkokul düzeyinde Türkçe dersi yazma becerisi alanında yaşanan sorunlar nelerdir?

\section{Araştırmanın Modeli}

\section{Yöntem}

Bu araştırma, meta-sentez yöntemi ile yürütülmüştür. Meta-sentez sistematik gözden geçirme gerektiren güçlü bir araştırma yöntemidir (Korhonen, Hakulinen-Viitanen, Jylha ve Holopoinen, 2012). 
Bu yöntem, belli bir konuda yapılmış nitel araştırma verilerinin bir arada değerlendirilmesi ihtiyacından doğmuştur (Paterson ve ark., 2009). Meta-sentez yönteminde aynı konu üzerinde yapılan nitel araştırmalar yine nitel yöntemin esaslarına uygun olarak eleştirel bir anlayışla değerlendirilmektedir (Çalık ve Sözbilir, 2014). Polat ve Ay'a (2016) göre meta-sentez araştırmalarında nitel araştırma bulgularının yanı sıra karma yöntemle yapılmış çalışmaların nitel bulgularına da yer verilebilir. Dinçer (2018) meta-sentezde sadece nitel verilerin ya da hem nitel hem de nicel verilerin birlikte kullanabileceği şeklinde iki farklı görüş olduğunu belirterek nicel verilerin meta-sentezde kullanılabilmesi için araştırma kapsamında ele alınan çalışmaların sonuçlarının ele alınıp tartışıması gerektiğini ifade etmiştir. Batdı (2019) da meta-sentezi nitel ve nicel verilerin birlikte değerlendirilebileceği bir araştırma olarak tanımlamaktadır. Bu hususlara bağlı olarak mevcut araştırma meta-sentez yöntemine uygun olarak gerçekleştirilmiştir. Finfgeld (2003) meta-sentez araştırmalarının amacının bireysel çalışmalardan hareketle daha bütüncül ve işlevsel yorumlar üretmek olduğunu belirtmektedir. Bu araştırmada, Türkiye'de ilkokul düzeyinde Türkçe dersinde yaşanan sorunları belirlemeye yönelik nitel, karma ve nicel yöntemlerle yapılmış çalışmaların bulguları metasentez yöntemine uygun olarak yorumlanıp karşılaştırılarak değerlendirilmiştir.

\section{Araştırma Grubu}

Araştırma kapsamına alınan çalışmaların amaçları, araştırma desenleri ve çalışma grupları makalenin anlaşılırlı̆ıını artırmak ve okuyucuya kolaylık sağlamak amacıyla aşağıda Tablo 1' de verilmiştir.

Tablo 1.

Araştırmaya Dâhil Edilen Çalışmalar

\begin{tabular}{|c|c|c|c|c|}
\hline Kod & Yazar/lar & Çalışmanın Amacı ve Türü & $\begin{array}{l}\text { Araştırma } \\
\text { Modeli }\end{array}$ & Çalışma Grubu \\
\hline Ç1 & $\begin{array}{l}\text { Babayiğit } \\
\text { (2019) }\end{array}$ & $\begin{array}{l}\text { Illkokul 1. sınıf öğrencilerinin dik temel yazı ile } \\
\text { kelime yazım hatalarının belirlenmesi } \\
\text { (Makale) }\end{array}$ & $\begin{array}{l}\text { Doküman } \\
\text { incelemesi }\end{array}$ & $\begin{array}{l}\text { Öğrenci } \\
\text { (84) }\end{array}$ \\
\hline Ç2 & $\begin{array}{l}\text { Ulu } \\
\text { (2019) }\end{array}$ & $\begin{array}{l}\text { İlkokul 1. sınıf öğrencilerinin dik temel yazılarını } \\
\text { okunaklılık ve yazma hataları açısından } \\
\text { değerlendirilmesi } \\
\text { (Makale) }\end{array}$ & $\begin{array}{l}\text { Tarama } \\
\text { deseni }\end{array}$ & $\begin{array}{l}\text { Öğrenci } \\
\text { (92) }\end{array}$ \\
\hline Ç3 & $\begin{array}{l}\text { Sarıkaya } \\
\text { ve } \\
\text { Sökmen } \\
\text { (2019) }\end{array}$ & $\begin{array}{l}\text { Yazma etkinliklerinin ilkokul öğrencileri } \\
\text { tarafından neden zor ve sıkıcı olarak } \\
\text { nitelendirildiğinin sınıf öğretmenlerinin } \\
\text { deneyim ve görüşleri doğrultusunda } \\
\text { belirlenmesi } \\
\text { (Tam metin bildiri) }\end{array}$ & $\begin{array}{l}\text { Değerlendir } \\
\text { meci } \\
\text { durum } \\
\text { çalışması }\end{array}$ & $\begin{array}{l}\text { Sınıf } \\
\text { öğretmeni } \\
(20)\end{array}$ \\
\hline Ç4 & $\begin{array}{l}\text { Çakır, } \\
\text { Arslan ve } \\
\text { Doğan } \\
\text { (2018) }\end{array}$ & $\begin{array}{l}\text { ilkokul öğretmenlerinin bitişik eğik yazıyı ve dik } \\
\text { temel harflerle yazıyı hangi gerekçelerle tercih } \\
\text { ettiklerini ve bitişik eğik yazı ve dik temel } \\
\text { harflerle kullanımında hangi güçlüklerle } \\
\text { karşılaştıklarını ortaya koymak } \\
\text { (Makale) }\end{array}$ & Olgubilim & $\begin{array}{l}\text { Sınıf } \\
\text { öğretmeni } \\
(85)\end{array}$ \\
\hline Ç5 & $\begin{array}{l}\text { Erdoğan, } \\
\text { Gülay ve } \\
\text { Uzuner } \\
(2017)\end{array}$ & $\begin{array}{l}\text { Sınıf öğretmenlerinin yazma güçlüğüne ilişkin } \\
\text { görüşlerinin belirlenmesi } \\
\text { (Makale) }\end{array}$ & Nitel & $\begin{array}{l}\text { Sınıf } \\
\text { öğretmeni } \\
(25)\end{array}$ \\
\hline Ç6 & $\begin{array}{l}\text { Bulut ve } \\
\text { Kuşdemir } \\
\text { (2017) }\end{array}$ & $\begin{array}{l}\text { Sesli okumadaki hataların ortaya konması } \\
\text { (Makale) }\end{array}$ & $\begin{array}{l}\text { Tarama } \\
\text { deseni }\end{array}$ & $\begin{array}{l}\text { Sınıf } \\
\text { öğretmeni } \\
\text { (116) }\end{array}$ \\
\hline
\end{tabular}




\begin{tabular}{|c|c|c|c|c|}
\hline Ç7 & $\begin{array}{l}\text { Babayiğit } \\
\text { ve Ökten } \\
\text { (2016) }\end{array}$ & $\begin{array}{l}\text { Illkokul dördüncü sınıf öğrencilerinin metin } \\
\text { türlerine göre dinlediğini anlama becerisinin } \\
\text { anlamlı farklılık gösterip göstermediğinin ve } \\
\text { sınıf öğretmenlerinin görüşlerinin belirlenmesi } \\
\text { (Makale) }\end{array}$ & Karma & $\begin{array}{l}\text { Sınıf } \\
\text { öğretmeni } \\
\text { (5) }\end{array}$ \\
\hline Ç8 & $\begin{array}{l}\text { Demir ve } \\
\text { İzci (2015) }\end{array}$ & $\begin{array}{l}\text { İlkokul 4. sınıf Türkçe dersi öğretiminde } \\
\text { karşılaşılan sorunları belirlemek ve bu } \\
\text { sorunların giderilmesine yönelik öğretmen } \\
\text { görüşlerini ortaya koymak } \\
\text { (Makale) }\end{array}$ & $\begin{array}{l}\text { Durum } \\
\text { çalışması }\end{array}$ & $\begin{array}{l}\text { Sınıf } \\
\text { öğretmeni } \\
(15)\end{array}$ \\
\hline Ç9 & $\begin{array}{l}\text { Altuntaş } \\
\text { ve Akyüz } \\
\text { (2015) }\end{array}$ & $\begin{array}{l}\text { 3. ve 4. sınıflarda dinleme eğitiminde } \\
\text { karşılaşılan güçlükleri öğretmen } \\
\text { doğrürüleri } \\
\text { (Makale) }\end{array}$ & Nitel & $\begin{array}{l}\text { Sınıf } \\
\text { öğretmeni } \\
(18)\end{array}$ \\
\hline Ç10 & $\begin{array}{l}\text { Kula, } \\
\text { Budak ve } \\
\text { Taşdemir } \\
(2015)\end{array}$ & $\begin{array}{l}\text { illkokul } 4 . \text { sınıf öğrencilerinin Türkçe } \\
\text { programında yer alan kazanımlar bağlamında } \\
\text { noktalama işaretlerini doğru ve yerinde } \\
\text { kullanma düzeylerinin tam öğrenme modeline } \\
\text { uygun olarak belirlenmesi } \\
\text { (Tam metin bildiri) }\end{array}$ & $\begin{array}{l}\text { Tarama } \\
\text { deseni }\end{array}$ & $\begin{array}{l}\text { Öğrenci } \\
\text { (59) }\end{array}$ \\
\hline Ç11 & $\begin{array}{l}\text { Tok ve } \\
\text { Ünlü } \\
\text { (2014) }\end{array}$ & $\begin{array}{l}\text { İlkokul, ortaokul ve lise düzeyindeki } \\
\text { programlarda yer alan Türkçe ve Edebiyat } \\
\text { derslerinde, yazma becerisinin geliştirilmesine } \\
\text { yönelik yaşanan sorunları ortaya koymak } \\
\text { (Makale) }\end{array}$ & $\begin{array}{l}\text { Bütüncül } \\
\text { çoklu } \\
\text { durum } \\
\text { deseni }\end{array}$ & $\begin{array}{l}\text { Sınıf } \\
\text { öğretmeni } \\
(20)\end{array}$ \\
\hline Ç12 & $\begin{array}{l}\text { Ateş, } \\
\text { Çetinkaya } \\
\text { ve } \\
\text { Yıldırım } \\
(2014)\end{array}$ & $\begin{array}{l}\text { İlkokul öğretmenlerin yazma güçlükleri } \\
\text { konusundaki bilgilerinin ve yazma güçüğü olan } \\
\text { öğrencilerle baş etme konusundaki yeterlik } \\
\text { algılarının belirlenmesi } \\
\text { (Makale) }\end{array}$ & Betimsel & $\begin{array}{l}\text { Sınıf } \\
\text { öğretmeni } \\
(226)\end{array}$ \\
\hline Ç13 & $\begin{array}{l}\text { Uygun ve } \\
\text { Katrancl } \\
(2013)\end{array}$ & $\begin{array}{l}\text { Sınıf öğretmenlerinin Türkçe derslerinde } \\
\text { karşılaştıkları sorunların belirlenmesi } \\
\text { (Tam metin bildiri) }\end{array}$ & Nitel & $\begin{array}{l}\text { Sınıf } \\
\text { öğretmeni } \\
(40)\end{array}$ \\
\hline Ç14 & $\begin{array}{l}\text { Yağcl, } \\
\text { Katrancı, } \\
\text { Erdoğan } \\
\text { ve Uygun } \\
(2012) \\
\end{array}$ & $\begin{array}{l}\text { Sınıf öğretmenlerinin kelime öğretiminde } \\
\text { karşılaştıkları sorunlar ile kullandıkları yöntem } \\
\text { ve tekniklerin belirlenmesi } \\
\text { (Makale) }\end{array}$ & Nitel & $\begin{array}{l}\text { Sınıf } \\
\text { öğretmeni } \\
(25)\end{array}$ \\
\hline Ç15 & $\begin{array}{l}\text { Altun, } \\
\text { Ekiz ve } \\
\text { Odabaşı, } \\
(2011)\end{array}$ & $\begin{array}{l}\text { Sınıf öğretmenlerinin karşılaştıkları okuma } \\
\text { güçlükleri ve bunları ortadan kaldırmak için } \\
\text { yaptıkları uygulamaların belirlenmesi } \\
\text { (Makale) }\end{array}$ & $\begin{array}{l}\text { Durum } \\
\text { çalışması }\end{array}$ & $\begin{array}{l}\text { Sınıf } \\
\text { öğretmeni } \\
(10)\end{array}$ \\
\hline Ç16 & $\begin{array}{l}\text { Yalar } \\
(2010)\end{array}$ & $\begin{array}{l}\text { Illkokul 3. sınıf Türkçe dersi öğretiminde } \\
\text { karşılaşılan sorunların öğretmen görüşlerine } \\
\text { göre değerlendirilmesi } \\
\text { (Makale) }\end{array}$ & Nitel & $\begin{array}{l}\text { Sınıf } \\
\text { öğretmeni } \\
(13)\end{array}$ \\
\hline Ç17 & $\begin{array}{l}\text { Önder } \\
\text { (2009) }\end{array}$ & $\begin{array}{l}\text { Illkokul 3. sınıf öğrencilerinin konuşma ve yazma } \\
\text { sorunlarının tespit edilmesi ve bu sorunlara } \\
\text { çözüm yollarının üretilmesi } \\
\text { (Yüksek lisans tezi) }\end{array}$ & Nitel & $\begin{array}{l}\text { Sınıf } \\
\text { öğretmeni } \\
(14) \\
\text { Öğrenci } \\
(317)\end{array}$ \\
\hline
\end{tabular}


Tablo 1 incelendiğinde ilkokul düzeyinde Türkçe derslerinde yaşanan sorunları belirlemeye yönelik 17 çalışma olduğu görülmektedir. Polat ve Ay (2016) literatürde nitel ve karma araştırmaların ele alındığı meta-sentez araştırmalarında yaklaşık 8-12 çalışmaya yer verildiğini belirtmektedir. Mevcut araştırma kapsamına nicel araştırmalar da alındığı için 17 çalışmanın bu ölçütü karşıllayabileceği düşünülmektedir. Bu çalışmaların sekiz tanesinin sadece yazma becerisine (Ç1, Ç2, Ç3, Ç4, Ç5, Ç10, Ç11, Ç12); iki tanesinin sadece dinleme becerisine (Ç7, Ç9); iki tanesinin sadece okuma becerisine (Ç6, Ç15); bir tanesinin kelime öğretimine (Ç14); bir tanesinin konuşma ve yazma becerisine (Ç17) ve üç tanesinin Türkçe dersinin geneline $(C ̧ 8, C ̧ 13, C ̧ 16)$ yönelik olduğu görülmektedir. Okuma yazma öğretimi sürecinin işleyişi farklı olduğu için okuma yazma öğretimi araştırma kapsamı dışında tutulmuştur. Ç1 ve Ç2'in çalışma grubu ilkokul 1. sınıf öğrencileri olmasına karşın her iki çalışmanın verilerinin Mayıs ayında toplanması ve araştırma içeriğinin okuma yazma öğretimi sürecine yönelik olmaması nedeniyle Ç1 ve Ç2 araştırma kapsamına alınmıştır.

\section{Verilerin Toplanması ve Analiz Edilmesi}

Polat ve Ay (2016) meta-sentez yöntemine uygun olarak yürütülen araştırmaların işlem basamaklarına yönelik çeşitli araştırmaları inceleyerek takip edilmesi gereken işlem basamaklarını aşağıdaki gibi belirlemiş ve bu araştırma, sırasıyla bu işlem basamaklarına uygun olarak yürütülmüştür.

(I) Araştırma sorularının belirlenmesi. (II) Konuya uygun anahtar kelimeler belirlenerek literatür taramasının yapılması. (III) Kaynakların elde edilmesi ve gözden geçirilerek değerlendirilmesi. (IV) Araştırma kapsamına alınma ölçütlerinin ve dâhil edilecek çalışmaların belirlenmesi. (V) Belirlenen çalışmaların incelenerek ortak temaların, alt temaların ve bunların benzer ve farklı yönlerinin belirlenmesi. (VI) Temalar ekseninde bulguların sentezlenmesi. (VII) Araştırma sürecinin ve elde edilen bulguların detaylı olarak raporlaştırılması.

Araştırma sürecinde önce araştırma soruları oluşturulmuş, ardından Google Akademik, YÖK Akademik ve YÖK Tez Merkezi veri tabanlarında "Türkçe, dinleme, konuşma, okuma, yazma" kavramları aranmış ve araştırmaların yapıldığı zaman dilimi açısından herhangi bir kısıtlama yapılmamıştır. Tarama sonucunda 88 çalışmaya ulaşılmış, bunlar başlık, özet, yöntem ve çalışma grupları incelenerek araştırma kapsamına alınacak çalışmalar belirlenmiştir. Çalışmalar kapsama alınırken çalışmaların ilkokul düzeyinde Türkçe dersinde yaşanan sorunlara yönelik olması ölçüt olarak alınmıştır. Bu ölçütleri sağlayan 17 çalışma belirlenmiş ve araştırma bu çalışmalar ile yürütülmüştür. Çalışmaların Türkçe dersi dinleme, konuşma, okuma ve yazma becerilerine yönelik olduğu tespit edilmiş ve çalışmaların bulguları bu temalar ve temalara uygun alt temalara göre sınıflandırılmıştır. Tema ve alt temalara uygun düşen veriler karşılaştırılıp sentezlenerek yeniden yorumlanmış, mevcut araştırmanın bulguları oluşturulmuş ve araştırma tüm yönleriyle raporlaştırılmıştır. Verilerin toplanması, analiz edilmesi ve temaların oluşturulması 25 Nisan- 31 Ağustos 2020 tarihleri arasında yapılmıştır.

\section{Geçerlik ve Güvenirlik}

Polat ve Ay (2016) meta-sentez araştırmalarının geçerlik ve güvenirliğini sağlamak için çalışmanın amacı ve araştırma sorularının açık bir şekilde ifade edilmesi; araştırmaya dâhil edilme ve hariç tutulma ölçütlerinin belirlenmesi; ulaşılan ve araştırmaya dâhil edilen çalışmaların yöntemi, alanı ve örneklemi gibi bilgilerin verilmesi; ortak temaların oluşturulma süreci ve araştırma için ayrılan süre hakkında bilgi verilmesi ile incelenen çalışmaların bulgularından örnekler verilmesi gerektiğini belirtmektedir. Bu ilkelere uygun olarak araştırmanın amacı ve soruları giriş bölümünün sonunda; araştırmaya dâhil edilme ölçütleri, ortak temaların oluşturulma süreci, harcanan süre verilerin toplanması ve analiz edilmesi bölümünde; araştırma kapsamındaki çalışmaların özellikleri çalışma grubu bölümünde ve çalışmalardan örnek kesitler bulgular bölümünde tabloların altındaki açıklamalarda belirtilmiştir. Temalarda yer alan alt temalar ile alt temalarda belirtilen bulguların doğru bir biçimde tasnif edilmesi süreci araştırmacı tarafından üç defa tekrar edilerek kontrol edilmiştir. Ayrıca araştırmanın tekrara yol açmaması için araştırma konusuna yakın olduğu düşünülen ve içerik analizi ile yapılan çalışmalar (Ceran, Aydın ve Onarıcıoğlu, 2018; Girmen, Kaya ve Bayrak, 2010; Polat, 2015; Tavşanlı ve Kaldırım 2018) incelenmiştir. 


\section{Etik Kurulu i̇zi}

Yapılan bu çalışmada "Yükseköğretim Kurumları Bilimsel Araştırma ve Yayın Etiği Yönergesi" kapsamında uyulması belirtilen tüm kurallara uyulmuştur. Yönergenin ikinci bölümü olan "Bilimsel Araştırma ve Yayın Etiğine Aykırı Eylemler" başlığı altında belirtilen eylemlerden hiçbiri gerçekleştirilmemiştir.

\section{Bulgular}

Araştırmanın bulguları dinleme, konuşma, okuma ve yazma temalarına uygun olarak sıralanmıştır. Araştırmanın dinleme teması ile ilgili bulgular Tablo 2'de sunulmuştur.

Tablo 2.

Dinleme Becerisi Alanında Yaşanan Sorunlar

\begin{tabular}{ll}
\hline \multicolumn{2}{l}{ Okul ve sınıfın özelliklerinden kaynaklanan sorunlar } \\
\hline Ç9 & Sınıfların kalabalık olması \\
Ç9 & Okul araç gereçlerinin yetersizliği \\
\hline \multicolumn{2}{c}{ Öğrencilerden kaynaklanan sorunlar } \\
\hline Ç8 & Öğrencilerin çabuk sıkılması \\
Ç8 & Öğrencilerin uygun dinleme pozisyonunu koruyamaması \\
Ç7-Ç8-Ç9 & Öğrencilerde dikkat ve motivasyon eksikliği \\
Ç7-ç9-Ç16 & Öğrencilerin söz varlığının yetersiz olması \\
Ç7-Ç9 & Öğrencilerin dinleme becerilerinin yetersiz olması \\
Ç9 & Öğrencilerin derse yönelik hazırbulunuşluk düzeyinin yetersizliği \\
ç9 & Öğrencilerin derse aç gelmesi \\
Ç9 & Sınıfta farklı yaş ve gelişimim özelliklerinde öğrenciler olması \\
Ç9 & Sınıfta aşırı hareketli öğrencilerin olması \\
Ç7 & Öğrencilerin okuma alışkanlığının olmaması \\
\hline Metinlerden ve etkinliklerden kaynaklanan sorunlar \\
\hline Ç8 & Gereksiz etkinliklerin varlığı \\
Ç7-ç9 & Metinlerin ve etkinliklerin uzun olması \\
Ç7-Ç9 & Metinlerin ve etkinliklerin öğrencilerin yaş ve gelişim özelliklerine uygun olmaması \\
Ç9 & Etkinlerin ilgi çekici olmaması \\
Ç9-ç13 & Etkinlik için ayrılan sürenin yetersiz olması \\
\hline Diğer & \\
\hline Ç7 & Öğretmenlerin öğrencilerin dikkatini çekememesi \\
Ç7 & Okuyan kişinin akıcı okuyamaması, vurgu ve tonlamalara dikkat etmemesi
\end{tabular}

Tablo 2 incelendiğinde dinleme ile ilgili yaşanan sorunları belirten toplam beş çalışma (Ç7, Ç8, Ç9, Ç13, Ç16) olduğu ve dinleme teması ile ilgili dört alt tema olduğu görülmektedir. Okul ve sınıfın özelliklerinden kaynaklanan sorunlar alt temasında sınıfların kalabalık olması, okul araç gereçlerinin yetersizliği; öğrencilerden kaynaklanan sorunlar alt temasında öğrencilerde dikkat ve motivasyon eksikliği, öğrencilerin söz varlığının yetersiz olması; metinlerden ve etkinliklerden kaynaklanan sorunlar alt temasında metinlerin ve etkinliklerin uzun olması, etkinlikler için ayrılan sürenin yetersiz olması; diğer alt temasında ise öğretmenlerin öğrencilerin dikkatini çekememesi ve okuyan kişinin akıcı okuyamaması, okurken vurgu ve tonlamalara dikkat etmemesinin etkili olduğu görülmektedir. Öğrencilerde dikkat ve motivasyon eksikliği alt teması Ç7 kodlu kaynak sayfa 10'da "Görüşme yapılan sınıf öğretmenleri, dinlediğini anlama engelleri olarak ... öğrencilerdeki dikkat eksikliğini belirtmişlerdir."; Ç8 kodlu kaynak sayfa 447'de "Öğretmenler, öğrencilerin dinleme becerilerini geliştirmede en çok karşılaştıkları sorunlara ilişkin olarak ... öğrencide motivasyon eksikliği ... şeklinde belirtmişlerdir." ç9 kodlu kaynak sayfa 297'de "Öğretmenlerin büyük çoğunluğu (15) öğrencilerde dikkat eksikliğinin olmasını güçlük olarak görmekte ..." ifadelerine bağlı olarak oluşturulmuştur. 
Araştırmanın konuşma teması ile ilgili bulgular Tablo 3'te sunulmuştur.

Tablo 3.

Konuşma Becerisi Alanında Yaşanan Sorunlar

\begin{tabular}{ll}
\hline \multicolumn{2}{l}{ Söyleyiş ile ilgili sorunlar } \\
\hline Ç8-Ç17 & Yöresel şivelerin konuşmaya etkisi \\
Ç8-Ç17 & Ses tonunu ayarlayamama, ses tonunun alçak ya da yüksek olması \\
Ç8-Ç17 & Ses/kelimeleri yanlış telaffuz etme \\
\hline Söz varlığı yetersizliğinden kaynaklı sorunlar \\
\hline Ç8 & Kelime tekrarının çok olması \\
Ç8 & Uzun cümleler kuramama \\
Ç16 & Akıcı konuşamama \\
Ç16-Ç17 & Sınırlı sayıda sözcük kullanma \\
Ç13-Ç17 & Söz varlığına bağlı olarak kelimeleri eksik cümleler kurma \\
Ç17 & Gereksiz kelimeler kullanma \\
Ç13-Ç17 & Yanlıs sözcük/ek kullanma \\
Ç17 & Türkçeyi eksik ve hatalı kullanma \\
Ç17 & Sözcüklere ek getirmeme ya da yanlış ek getirme \\
Ç17 & Konuşurken zorlanma \\
\hline Diğer & \\
\hline Ç8 & İinsiz konuşma \\
Ç8 & Topluluk karşısında konuşamama \\
Ç8 & ilgisiz konularda konuşma \\
Ç8 & Konuşma etkinliklerinin azlığı \\
Ç13 & Sürenin yetersizliği \\
\hline
\end{tabular}

Tablo 3 incelendiğinde konuşma ile ilgili yaşanan sorunları belirten toplam dört çalışma (Ç8, Ç13, Ç16, Ç17) olduğu ve konuşma teması ile ilgili üç alt tema olduğu görülmektedir. Söyleyiş ile ilgili yaşanan sorunlar alt temasında yöresel şivelerin konuşmaya etkisi, ses tonunu ayarlayamama, ses tonunun alçak ya da yüksek olması; söz varlığı yetersizliğinden kaynaklanan sorunlar alt temasında sınırlı sayıda sözcük kullanma, söz varlığına bağlı olarak kelimeleri eksik cümleler kurma; diğer alt temasında izinsiz konuşma, topluluk karşısında konuşamamanın etkili olduğu görülmektedir. Öğrencilerde ses/kelimeleri yanlış telaffuz etme alt teması Ç7 kodlu kaynak sayfa 448' de "Öğretmenler, öğrencilerin konuşma becerilerini geliştirmede en çok karşılaştıkları sorunlara ilişkin olarak; özellikle ögrretmenlerin çoğu ... kullanılan kelimelerin yanlış telaffuz edildiğini belirtmişlerdir."; Ç17 kodlu kaynak sayfa 46 'da "... kelimelerin yanlış telaffuz edilmesi sorunu örneklem dahilindeki her okulda gözlemlenmiştir." ifadelerine bağlı olarak oluşturulmuştur.

Araştırmanın okuma teması ile ilgili bulgular Tablo 4'te sunulmuştur.

Tablo 4.

Okuma Becerisi Alanında Yaşanan Sorunlar

\begin{tabular}{ll}
\hline Akıcı ve anlamlı okumayla ilgili sorunlar \\
\hline Ç16 & Akıcı okuyamama \\
Ç8 & Ses tonunu ayarlayamama \\
Ç6-Ç8 & Telaffuzda güçlük çekme \\
ç8 & Yöresel şivelerin olumsuz etkileri \\
ç8 & Öğrencinin dikkat yetersizliği \\
ç8-Ç13 & Okuma alışkanlığının olmaması \\
Ç8 & Okuma metninin öğrenciye uygun olmaması \\
Ç8-Ç15 & Noktalama işaretlerine uygun olarak okuyamama
\end{tabular}




\begin{tabular}{ll} 
Ç15 & Yavaş okuma \\
Ç15 & Hızlı okuma \\
Ç6-Ç15 & Okurken sürekli geri dönüş ve tekrar yapma \\
Ç13-Ç15 & Okuduğunu anlayamama \\
Ç6-Ç13-Ç15 & Heceleyerek okuma \\
Ç6 & Okurken parmak ya da kalemle takip etme \\
Ç15 & Okuma yazma becerisini edinememiş olma \\
\hline Söz varlığıyla ilgili sorunlar \\
\hline Ç16 & Söz varlığının yetersizliği \\
Ç14 & Soyut kelimeleri öğrenmede zorlanma \\
Ç14 & Kelimeleri ilk kez duyma/tanımama \\
Ç14 & Yabancı kökenli kelimeleri öğrenmede zorlanma \\
Ç14 & Öğrenilen kelimeleri unutma \\
\hline Okuma hatalarıyla ilgili sorunlar \\
\hline Ç6-Ç15 & Harf yutma \\
Ç15 & Kelimelerin başını doğru okuyup sonunu uydurma \\
Ç6-Ç15 & Eksik heceli okuma \\
Ç15 & Yanlış heceleme \\
Ç6-Ç15 & Bazı harfleri karıştırma \\
Ç6-Ç15 & Okunması zor olan kelimelerde telaffuz hatası yapma \\
Ç6 & Cümlede olmayan kelimeyi cümleye ekleyerek okuma \\
Ç2-Ç6-Ç15 & Kelimeye yeni ek ekleme \\
\hline Diğer & \\
\hline Ç6 & Okurken gereksiz vücut hareketleri yapma \\
Ç8-Ç13 & Sürenin yetersizliği \\
Ç8 & Yöntem konusunda öğretmen veli çelişkisi \\
\hline
\end{tabular}

Tablo 4 incelendiğinde okuma ile ilgili yaşanan sorunları belirten toplam altı çalışma (Ç6, Ç8, Ç13, Ç14, Ç15, Ç16) olduğu ve okuma teması ile ilgili dört alt tema olduğu görülmektedir. Akıcı ve anlamlı okumayla ilgili sorunlar alt temasında heceleyerek okuma, okuduğunu anlayamama, okurken sürekli geri dönüş ve tekrar yapma, noktalama işaretlerine uygun olarak okuyamama; söz varlığıyla ilgili sorunlar alt temasında söz varlığının yetersizliği, öğrenilen kelimeleri unutma, kelimeleri ilk kez duyma tanımama; okuma hatalarıyla ilgili sorunlar alt temasında kelimeye yeni ek ekleme, okunması zor olan kelimelerde telaffuz hatası yapma, eksik heceli okuma; diğer alt temasında sürenin yetersizliği, okurken gereksiz vücut hareketleri yapmanın etkili olduğu görülmektedir. Öğrencilerde okuduğunu anlamama alt teması Ç13 kodlu kaynak sayfa 262 'de "öğrencilerin heceleyerek okuma nedeniyle okuduğunu anlamakta güçlük çekmeleri"; Ç15 kodlu kaynak sayfa 89'da "Tablo 2 incelediğinde bazı okuma güçlükleriyle daha sık karşılaşıldığını görmekteyiz. ... okuduğunu anlamama ... güçlükleri gözlemlediği görülmektedir." ifadelerine bağıı olarak oluşturulmuştur.

Araştırmanın yazma teması ile ilgili bulgular Tablo 5'te sunulmuştur.

Tablo. 5.

Yazma Becerisi Alanında Yaşanan Sorunlar

\begin{tabular}{ll}
\hline Yazım kuralları ve noktalama işaretleri ile ilgili sorunlar \\
\hline Ç17 & Cümle başında büyük harf kullanmama \\
Ç17 & Özel isimlerin ilk harfini büyük yazmama \\
Ç2-Ç5-Ç10-Ç11-Ç17 & Yazım ve noktalama işaretleri ile ilgili yanlışlar yapma \\
Ç17 & Paragraf başlarını belirtmeme \\
Ç17 & Birleşik yazılması gereken heceyi/harfi ayrı yazma
\end{tabular}




\begin{tabular}{|c|c|}
\hline Ç17 & Ayrı yazılması gereken heceyi/harfi birleşik yazma \\
\hline Ç10-Ç17 & Kesme işaretini yanlış kullanma \\
\hline Ç2 & Satıra sığmayan kelimeyi doğru biçimde hecelerine ayıramama \\
\hline Ç8-Ç10-Ç11-Ç12-Ç17 & Yazarken yazım kuralları ve noktalama işaretlerini uygulamama \\
\hline \multicolumn{2}{|c|}{ Yazmanın fiziksel boyutu ile ilgili sorunlar } \\
\hline Ç1-Ç2 & Harfler arasında uygun boşluk bırakmama \\
\hline Ç1-Ç2-Ç5-Ç17 & Eksik harf/hece kelime yazma \\
\hline Ç1-Ç2-Ç17 & Fazla harf/hece kelime yazma \\
\hline Ç5-Ç17 & Yanlış harf/ek yazma \\
\hline Ç5 & Harfleri yanlış yazma \\
\hline Ç5 & Harf atlama \\
\hline Ç17 & Kenar boşluklarına dikkat etmeme \\
\hline Ç1 & Harf değiştirme \\
\hline Ç1 & Hece ekleme \\
\hline Ç1-Ç5-Ç12 & Biçim, ebat, boşluk, satır hizasında yazamama gibi hatalar \\
\hline Ç12 & Estetik olmayan yazılar yazma \\
\hline Ç4-Ç5-Ç12 & Okunaklı yazamama \\
\hline Ç12 & Yazım hatalarının zaman geçse bile düzeltilememesi \\
\hline Ç5-Ç8 & Yanlış telaffuz edilen kelimelerin yanlış yazııması \\
\hline \multicolumn{2}{|c|}{ Öğretmenlerin yanlış tutum ve davranışlarından kaynaklanan sorunlar } \\
\hline Ç12 & İyi bir eğitim vermeme \\
\hline Ç5-Ç12 & Öğrencilerle yeterince ilgilenmeme \\
\hline Ç3 & Yazmaya gereken önemin verilmemesi \\
\hline Ç3-Ç5-Ç11-Ç12 & Öğretmenin yazma eğitimi için ayırdığı sürenin yetersizliği \\
\hline Ç3 & Yazılı metinlere gerekli dönüt ve düzeltmenin verilmemesi \\
\hline Ç3 & Okuma etkinliklerine yazma etkinliklerine göre daha fazla önem verilmesi \\
\hline Ç11 & Öğretmenlerin yazma yöntem ve tekniklerini kullanmaması \\
\hline Ç5-Ç12 & Öğrencilere model olmama \\
\hline \multicolumn{2}{|c|}{ Öğrencilerin yazma becerisi gelişimini engelleyen bilişsel, duyuşsal ve devinişsel sorunlar } \\
\hline Ç5-Ç11 & Öz güven eksikliği \\
\hline Ç5-Ç12 & Önemsememe, ilgisizlik \\
\hline Ç5-Ç12 & Dikkat dağınıklığı veya eksikliği \\
\hline Ç5-Ç12 & İsteksizlik, yazmayı sevmeme \\
\hline Ç3-Ç5 & Öğrencilerin yazma ile ilgili olumsuz duygu ve düşüncelere sahip olması \\
\hline Ç3 & Hata yapma korkusu \\
\hline Ç3 & Yazı yazarken aktif olamadıkları için öğrencilerin çabuk sıkılmaları \\
\hline Ç5-Ç11-Ç12 & $\begin{array}{l}\text { Devinişsel becerilerdeki yetersizlik (kas gelişimi, el-göz koordinasyonu, kalem } \\
\text { tutma vb.) }\end{array}$ \\
\hline Ç3 & Öğrencilerin çabuk yorulması \\
\hline Ç12 & Zihinsel yetersizlik \\
\hline Ç5-Ç12 & Yeteneksizlik \\
\hline Ç4-Ç16 & Akıcı yazamama \\
\hline Ç4-Ç5-Ç8 & Yavaş yazma \\
\hline Ç3 & Yazılı görevlerin gereksiz görülmesi \\
\hline Ç11 & Kitap okumama \\
\hline Ç11 & Yazarken plan yapmama \\
\hline Ç11-Ç16 & Söz varlığının yetersiz olması \\
\hline
\end{tabular}




\begin{tabular}{ll}
\hline Yazmanın kendine has özelliklerden kaynaklanan sorunlar \\
\hline Ç3 & Yazmanın bilişsel açıdan zorluklarının olması \\
Ç3 & Yazmanın devinişsel açıdan zorluklarının olması \\
Ç3 & Birçok bilişsel, duyuşsal, devinişsel beceriyi aynı anda gerektirmesi \\
Ç11-Ç13 & Yazmanın zaman alması \\
\hline Veli yaklaşımlarından kaynaklanan sorunlar \\
\hline Ç11 & Velilerin/ailelerin sesi harf olarak öğretmeleri \\
Ç3 & Velilerin/ailelerin yazmaya yönelik tutum ve davranışlarının olumsuz etkileri \\
Ç3-Ç5 & Velilerin/ailelerin yazı etkinlerine katılmaması ve gerekli takibi yapmaması \\
\hline Diğer & \\
\hline Ç4 & Öğretmenler, öğrenciler ve veliler için adaptasyon gerektirmesi (Bitişik eğik \\
& yazıdan dik temel harflerle yazmaya geçenler için) \\
Ç4 & Yeni materyaller gerektirmesi (Bitiş̧ik eğik yazıdan dik temel harflerle yazmaya \\
& geçenler için) \\
Ç11 & Teste dayalı sınav \\
Ç12 & Yazma becerisinde akranlara göre gerilik \\
Ç8 & Bitişik eğik yazı yazarken sorun yaşama \\
Ç11-Ç12 & Kendini yazılı olarak ifade edememe \\
\hline
\end{tabular}

Tablo 5 incelendiğinde yazma ile ilgili yaşanan sorunları belirten toplam on iki çalışma (Ç1, Ç2, Ç3, Ç4, Ç5, Ç8, Ç10, Ç11, Ç12, Ç13, Ç16, Ç17) olduğu ve yazma teması ile ilgili yedi alt tema olduğu görülmektedir. Yazım kuralları ve noktalama işaretleri ile ilgili sorunlar alt temasında yazarken yazım kuralları ve noktalama işaretlerini uygulamama, yazım ve noktalama işaretleri ile ilgili yanlışlar yapma, kesme işaretini yanlış kullanma; yazmanın fiziksel boyutu ile ilgili sorunlar alt temasında eksik harf/hece kelime yazma, biçim, ebat, boşluk, satır hizasında yazamama gibi hatalar, okunaklı yazamama; ögretmenlerin yanlış tutum ve davranışlarından kaynaklanan sorunlar alt temasında öğretmenin yazma eğitimi için ayırdığı sürenin yetersizliği, öğrencilerle yeterince ilgilenmeme, öğrencilere model olmama; öğrencilerin yazma becerisi gelişimini engelleyen bilişsel, duyuşsal ve devinişsel sorunlar alt temasında devinişsel becerilerdeki yetersizlik (kas gelişimi, el-göz koordinasyonu, kalem tutma vb.), yavaş yazma, dikkat dağınıklığı veya eksikliği, isteksizlik, yazmayı sevmeme; yazmanın kendine has özelliklerden kaynaklanan sorunlar alt temasında yazmanın zaman alması, birçok bilişsel, duyuşsal, devinişsel beceriyi aynı anda gerektirmesi; veli yaklaşımlarından kaynaklanan sorunlar alt temasında velilerin yazı etkinlerine katılmaması ve gerekli takibi yapmaması, velilerin sesi harf olarak öğretmeleri; diğer alt temasında yazma becerisinde akranlara göre gerilik ve teste dayalı sınavın etkili olduğu görülmektedir. Öğrencilerde kendini yazılı olarak ifade edememe alt teması Ç11 kodlu kaynak sayfa 82 'de "Öğretmenlere göre ilkokul düzeyinde öğrencilerden kaynaklanan sorunların basında $(f=16)$ öğrencilerin kendilerini ifade edememesi gelmektedir."; Ç12 kodlu kaynak 483'te "Kendini yazılı ifade edememe (yazılı anlatım/ifade güçlüğü)" ifadelerine bağlı olarak oluşturulmuştur.

\section{Tartışma ve Sonuç}

İlkokul düzeyinde Türkçe derslerinde yaşanan sorunları ilgili çalışmalardan hareketle ortaya koymanın amaçlandığı bu araştırmada elde edilen bulgular dinleme, konuşma, okuma ve yazma temaları sırasına uygun olarak tartışılmıştır.

Araştırmanın bulguları incelendiğinde ilkokul öğrencilerinin dinleme becerisi alanında yaşadıkları sorunları belirlemeye yönelik ikisi doğrudan olmak üzere toplam beş çalışma olduğu görülmektedir. Babayiğit ve Ökten'in (2016) ilkokul 4. sınıf öğrencilerinin dinlediklerini anlama düzeylerinin belirlenmesini amaçladıkları çalışmada katılımcı öğretmenler öğrencilerin büyük bir kısmının dinleme becerisinde sorun yaşadıklarını belirtmişlerdir. Doğan ve Özçakmak (2014) dinleme becerisi ile ilgili lisansüstü tezleri incelemiş ve bahsedilen tezlerin sadece üçte birinin doğrudan dinleme becerisi ile ilgili olduğunu diğer çalışmaların ise dinlemeyi diğer becerilerle birlikte ele alan çalışmalar 
olduğunu belirtmiştir. Bu bakımdan mevcut araştırmada ele alınan çalışmalarda dinlemeye yönelik çalışmaların oranı bu bulguyla örtüşmektedir. Girmen vd. (2010) tarafından Türkçe eğitimi alanında yaşanan sorunları belirlemek amacıyla yürütülen çalışmada dinleme becerisi ile ilgili yapılan çalışmaların yetersiz olduğu belirlenmiştir. Dinlemenin başlı başına bir beceri olmanın ötesinde analiz, sentez, ilişkilendirme ve sorgulama gibi çeşitli zihinsel işlemleri içererek (Babayiğit, 2017) diğer becerilerin edinilmesi ve geliştirilmesinin temeli olması daha fazla önemsemesini gerektirmektedir. Bu nedenle dinleme becerisinin diğer becerilerle olan ilişkisi de göz önüne alınarak dinleme becerisine yönelik müstakil çalışmalar yapılıp dinlemenin boyutları ve gelişimi daha net bir biçimde ortaya konabilir.

Yıldız, Alaçam Akşit ve Uyar (2016) öğretmenlerin, öğrencilerin dinleme davranışlarını analiz ederek onların dinleme davranışlarını olumsuz etkileyen unsurları ortadan kaldırması gerektiğini ifade etmişlerdir. Bu araştırmada incelenen çalışmalarda, öğrencilerin dikkat ve motivasyon eksikliğinin olması ve söz varlığının yetersizliğinin dinleme becerisini olumsuz yönde etkileyen sebeplerin başında geldiği görülmektedir. Çiftçi (2007) de öğrencilerin dinlemeye odaklanamamalarının önemli bir sorun olduğunu belirterek dinleme sürecinde dikkat ve motivasyona vurgu yapmıştır. Acat'ın (2003) dinlemenin ancak bireyin istemesiyle gerçekleşen bir davranış olduğunu ve dinleme becerisi de dâhil olmak üzere Türkçe dersi becerilerinin geliştirilmesi için öğrencilerin söz varlığının zengin olması gerektiğini vurgulaması araştırma sonuçları ile örtüşmektedir. Bu nedenle öğretmenlerin, öğrencilerin dikkat ve motivasyonlarını artırmaya ve söz varlığını zenginleştirmeye yönelik çalışmalar yapması önem arz etmektedir. Ayrıca öğrencilerin söz varlığının zengin olması onların dinleme ürünlerini anlamalarını, bu da dikkat ve motivasyonlarını olumlu yönde etkileyecek ve öğrencilerin öğrenme öğretme süreçlerinden daha çok faydalanmalarını sağlayacaktır.

Araştırma kapsamındaki çalışmalar incelendiğinde öğrencilerin konuşma becerisinde yaşadıkları sorunları konu edinen biri doğrudan olmak üzere toplam dört çalışma olduğu görülmektedir. Bu çalışmalarda öğrencilerin konuşma becerisinde yaşadıkları sorunların önemli bir kısmının söz varlığı yetersizliğinden kaynaklandığı belirtilmektedir. Konuşma insan zihninde başlayıp sözcükler yardımıyla ortaya çıkan bir beceridir (Güneş, 2014). Bu durum söz varlığı ile konuşma arasındaki ilişkiyi ortaya koymaktadır. Bireylerin öğrenme yaşantıları sonucunda belleklerinde depoladıkları birikim olarak tanımlanan söz varlığının gelişimini en verimli şekilde desteklemek Türkçe dersi ile mümkün olmaktadır (Özbay ve Melanlıoğlu, 2008). Bu nedenle öğrencilerin akıcı konuşmaları için söz varlığını geliştirecek etkinlikler yapılması gerekmektedir (Kuru ve Güneş, 2017). Araştırmada incelenen çalışmalara göre öğrencilerin konuşma becerilerinin gelişimini engelleyen bir diğer husus ise metinlerden kaynaklanan sorunlardır. Türkçe ders kitaplarında yer alan metinler geçmişten günümüze kadar dil becerilerinin öğretiminde kullanılmıştır (Güneş, 2013). Metinlerin ardından verilen etkinlikler aracılı̆ı ile öğrencilerin kazanımları edinmesi beklenmektedir. Bu nedenle metinler ve etkinliklerin nitelikli olması öğrenme öğretme süreçleri için ayrılan zamanın verimli kullanılmasını ve öğrencilerin kazanımları daha kısa sürede edinmesini sağlayacaktır.

Öğrencilerin okuma becerisinde yaşadıkları sorunların ağırlıklı olarak okuma hataları ile akıcı ve anlamlı okumayla ilgili olduğu görülmektedir. Mevcut araştırmada belirtilen okuma hatalarına, benzer birçok araştırmada ulaşılmıştır (Akyol ve Temur, 2006; Bayat, 2015; Bilge ve Sağır, 2017; Bulut ve Kuşdemir, 2017; Seçkin Yılmaz ve Baydık, 2017). Akıcı ve anlamlı okuma kavramları birbirleriyle ilişkili kavramlar olup akıcı okuma metni en doğru biçimde anlamayı sağlayan, okuma hatalarından arınmış hız ve prozodiye sahip okuma biçimidir (Çeliktürk Sezgin ve Akyol, 2015; Çetinkaya, Yıldırım ve Ateş, 2017; Yılmaz, 2008). Uzunkol (2013) tarafından öğrencilerin akıcı okumada yaptıkları hataları gidermeyi amaçlayan çalışmada öğrencilerin sıklıkla tekrarlı okuma, ekleme yapma, atlama gibi okuma hataları yaptıkları tespit edilmiştir. Tespit edilen bu hatalar mevcut araştırmanın bulguları ile örtüşmektedir. Seçkin Yılmaz ve Baydık (2017) öğrencilerin okuma hatalarından arınmış bir şekilde doğru ve hızlı okuyabildiklerinde metni anlamaya odaklanabileceğini belirtmiştir. Bunu sağlamak amacıyla Çaycı ve Demir (2006) öğrencilerin okuma sırasında yaşadıkları sorunları aşmaları için özellikle ilkokul düzeyinde kelime tanıma ve ayırt etme yoluyla öğrencilerin söz varılılarının geliştirilmesini önermekte ve ilkokul öğrencilerinin kullandıkları kelimelerin derlenmesi ve söz varlıklarının geliştirilmesine yönelik çalışmaların çok daha fazla yapııması gerektiğini belirtmişlerdir. Hatta bu alanda Milli Eğitim Bakanlığı 
(2018) Talim ve Terbiye Kurulu Başkanlığı sorumluluğunda 2. sınıftan 12. sınıfa kadar öğrencilerin kullandıkları sözcükleri sınıflandırmak ve derlemek için Türkçe Söz Varlığı Projesi'ni hayata geçirmiştir. $\mathrm{Bu}$ projede 26 ilden toplam bir milyon öğrenciye ulaşmak hedeflenmektedir. Mevcut araştırma kapsamında değerlendirilen çalışmaların sadece bir tanesinin kelime öğretimi ile ilgili olması bu alanda daha fazla araştırma yapılması gerekliliği ile örtüşmektedir. Türkçe dil becerilerinin hemen hemen hepsinin gelişiminde bir engel olarak karşımıza çıkan söz varlığı yetersizliği araştırmalarda araştırmacılar, eğitim öğretim sürecinde öğretmenler tarafından daha fazla önemsenirse öğrencilerin dil gelişimi daha hızlı bir biçimde sağlanabilir.

Öğrencilerin okuma becerisine yönelik yapılan birçok çalışmada (Aktaş ve Çankal, 2019; Bozkurt ve Memiş, 2013; Katrancı, 2015; Yamaç ve Çeliktürk Sezgin, 2018; Yıldız, 2013; Yıldız ve Akyol, 2011) okuma motivasyonuna dikkat çekilmiş ve öğrencilerin okuma alışkanlığı edinebilmesi için okuma motivasyonunun gerekliliği ifade edilmiştir. Özellikle okuma motivasyonu ile okuduğunu anlama düzeyleri arasında yakın bir ilişki olduğu bilinmektedir (Akyol ve Sural, 2020). Ancak araştırma kapsamındaki çalışmalarda öğrencilerin okuma motivasyonu yetersizliğine vurgu yapılmamıştır. Özellikle iki çalışmada (ç8, ç13) öğrencilerin okuma alışkanlığının olmaması sorun olarak belirtildiği halde okuma motivasyonu sorun olarak belirtilmemiştir. Oysa Şahin (2019) okuma davranışında motivasyonun etkin biçimde rol aldığını ifade etmekte ve öğrencilerin okuma motivasyonunu artırmaya yönelik tedbirler alınmasını önermiştir. Mevcut araştırmada incelenen çalışmalarda okuma motivasyonu yetersizliğinin bir sorun olarak bildirilmemesi katılımcıların daha çok öğrencilerin okuma hatalarına odaklanmasından kaynaklanabilir. Çünkü okuma hataları motivasyon kavramına göre daha somut ve gözlemlenebilen bir durumdur. Bu durum öğretmenlerin okuma ile ilgili sorunların temelinde yatan motivasyon yetersizliğini göz ardı etmelerine neden olmamalıdır. Özellikle okuma alışkanlığı kazanmak için kritik bir dönem olan ilkokulda öğrencilerin okuma motivasyonlarını yükseltmek için öğretmenlerin etkinlikler planlamaları diğer okuma sorunlarının da ortadan kalkmasını sağlayacaktır.

Araştırma kapsamında incelenen çalışmalardan dokuz tanesi doğrudan olmak üzere toplam 11 çalışma yazma becerisi ile ilgilidir. Bu beceriye yönelik çalışmaların diğer becerilere göre daha fazla olduğu söylenebilir. Yapılan çalışmalarda öğrencilerin yazma becerisinde yaşadıkları sorunların birçok faktörden etkilendiği görülmektedir. Özellikle noktalama işaretlerini kullanma, yazım kurallarını uygulama, yazının okunaklılığı ve yazmanın fiziksel boyutu ile ilgili sorunlara sıklıkla rastlandığı görülmektedir. Tok ve Erdoğan (2017) tarafından ilkokul öğrencilerinin yazma becerilerinin incelendiği çalışmada benzer sonuçlara ulaşılmıştır. Bahsedilen bu çalışmada öğrencilerin yazılarının okunaklıı̆ı̆ bir sorun olarak saptanmış ve öğretmenlerin öğrencilerin mekanik yazma becerilerini geliştirmek için etkinlikler tasarlamaları önerilmiştir. Arslan Özer ve Bağcı (2018) yazının okunaklılığı ile anlam ilişkisine dikkat çekerek yazıdaki anlamın ancak yazının okunaklılı̆ı ile ortaya çıkabileceğini belirtmektedir. Arslan ve Bağcı (2017) bir sınıftaki öğrencilerin yazı becerileri açısından farklı özelliklere sahip olduğunu, bu durumun öğretmenlerin işini zorlaştırdığını belirtmiştir. Bütün bu bilgiler ışığında öğrencilerin okunaklı yazı yazmaları için bireysel ve sürekli olarak takip edilmesi gerektiği sonucuna ulaşılabilir.

Yazma becerisi ile ilgili araştırmanın bir diğer önemli sonucu ise öğretmenlerin yanlış tutum ve davranışlarının öğrencilerin yazma becerisini olumsuz etkilemesidir. Kuşdemir, Katrancı ve Arslan (2018) öğretmenlerin derslerde yazı çalışmalarına yeterince yer vermemelerinden dolayı öğrencilerin okunaklı yazı yazmalarının olumsuz etkilendiğini belirtmişlerdir. Mevcut araştırma kapsamındaki dört çalışmada öğretmenlerin yazma becerisi için yeterli zamanı ayırmamasının belirtilmesi bu durumu doğrulamaktadır. Demir (2018) yazım eğitimi kavramına dikkat çekerek dilin yazıya geçirilmesi ile ilgili kuralların eğitim öğretim sürecinde öğrencilere kazandırılmasına vurgu yapmıştır. Bu nedenle yazım eğitimi sürecinin yürütülmesinden sorumlu olan öğretmenlerin bu konuda daha bilinçli davranmaları sürecin verimini artıracaktır. Tağa ve Ünlü (2013) tarafından yürütülen araştırmada katılımcı öğretmenler, öğrencilerin yazma becerisinin gelişiminde öğretmenlerden kaynaklanan sorunlarla ilgili olarak öğretmenlerin konu hakkında gelişmeleri takip edememesine vurgu yapmışlardır. Bu nedenle öğretmenlerin periyodik olarak yazma becerisi ile ilgili hizmet içi eğitim almaları öğretmenlerden kaynaklanan sorunları azaltabilir. 
Yazma becerisinin en önemli alanlarından biri olan yazılı anlatım becerisindeki sorunlara sadece iki çalışmada $(C ̧ 11$, Ç12) değinilmiştir. Yazıı ı anlatımda amaç bireyin yaşam içerisinde kendisini doğru olarak ifade etmesini sağlamaktır (Temel ve Karancı, 2019). Yazım eğitimi bu kadar önemli bir beceri olmasına karşın Ulu'ya (2018) göre hem okullarda yürütülen eğitim öğretim etkinliklerinde hem de Türk milli eğitim sisteminde ihmal edilen bir alan olmuştur. Yazma analiz, sentez ve değerlendirme gibi karmaşık zihinsel süreçleri gerektirdiğinden dil becerileri içinde öğrenciler tarafından kazanılması en zor olan beceri olarak tanımlanabilir (Batur ve Bitir 2019). Buna karşın yazmanın hem ilgili araştırmalarda hem de eğitim öğretim sürecinde yeterli ilgiyi görmemesi öğrencilerin yazma alanında yaşadığı sorunları artırabilir. Aydın (2014) bu olumsuzlukları ortadan kaldırmak amacıyla öğrencilerin okuma becerisinin gelişimi için okullarda uygulanan serbest okuma saatine benzer şekilde serbest yazım saati uygulanmasını önermiştir.

Araştırma, araştırmacının ulaştığı kaynaklarla sınırlıdır. Ayrıca araştırmanın bir diğer sınırlılı̆ı ise araştırmacının çalışmalardaki ham verilere ulaşamamasıdır. Ham verilere ulaşılması durumunda araştırma kapsamındaki çalışmaların verilerinin birbirlerine benzer ve farklı olan yanları görülerek analizler sayesinde daha ayrıntılı bilgilere ulaşılabilir.

Araştırmadan elde edilen bulgulara dayalı olarak aşağıdaki önerilerde bulunulmuştur:

(I) illkokul düzeyinde Türkçe dersinde yaşanan sorunların tespit edilmesi öğrenme öğretme sürecinin iyileştirilmesine katkı sağlayacağı için ilkokul öğrencilerini kapsayan çalışmaların artırılması gerekmektedir.

(II) Yapılan araştırmaların belli dil becerilerinde yoğunlaşmayıp intiyaca odaklı olabilmesi için Milli Eğitim Bakanlığı tarafından ihtiyaç analizi yapılarak araştırmalara yön verilebilir.

(III) Dil becerileri arasında ihmal edilen beceri olmaması için araştırmacıların ihtiyaçlara odaklanması faydalı olacaktır.

(IV) Araştırmaların, yaşanan sorunların çözümüne hizmet edebilmesi için sorunların tespiti ve tespit edilen sorunların giderilmesi amacıyla sorun ve çözüm ilişkili uzun soluklu araştırmalar planlanabilir.

(V) illkokul öğrencilerinin söz varlı̆ıını geliştirmeyi amaçlayan araştırmalar yapılabilir.

\section{Yazarların Katkı Oranı}

Bu makale, tek başına yazar tarafından hazırlanmıştır.

\section{Çıkar Çatışması}

Yazarın, bu makale ile ilgili olarak herhangi bir kurum ya da kişi ile çıkar çatışması yoktur.

\section{Kaynaklar}

Acat, M. B. (2003). Kavram haritalarının Türkçe öğretiminde kullanımı. Kuram ve Uygulamada Eğitim Yönetimi, 34(34), 168-193.

Akın, E. ve Çeçen, M. A. (2015). Çoklu ortama dayalı Türkçe öğretimine ve çoklu ortam araçlarına yönelik öğrenci görüşleri. Turkish Studies International Periodical For The Languages, Literature and History of Turkish or Turkic, 10(7), 51-72.

Aktaş, E. ve Çankal, A. O. (2019). Akıcı Okuma stratejilerinin 4.sınıf Türkçe derslerinde okuduğunu anlama becerisine ve okuma motivasyonuna etkisi. Zeitschrift Für Die Welt Der Türken / Journal of World of Turks 11(1), 85-114.

Akyol, H. (2019). Yeni programa uygun Türkçe öğretim yöntemleri. Ankara: Pegem Akademi.

Akyol, H. ve Sural, Ü. Ç. (2020). Okuma, okuduğunu anlama ve okuma motivasyonunun geliştirmesi: bir eylem araştırması. Eğitim ve Bilim, Erken Görünüm, 1-24.

Akyol, H. ve Temur, T. (2006). illköğretim üçüncü sınıf öğrencilerinin okuma düzeyleri ve sesli okuma hataları. Ekev Akademi Dergisi, 29(25), 9-274.

Altun, T. ve Batmaz, O. (2018). Bitişik eğik yazı uygulaması zorunluluğunun kaldırılmasına ilişkin sınıf öğretmenlerinin görüşleri. Electronic Turkish Studies, 13(11), 169-188. 
*Altun, T., Ekiz, D. ve Odabaşi, M. (2011). Sınıf öğretmenlerinin sınıflarında karşılaştıkları okuma güçlüklerine ilişkin nitel bir araştırma. Dicle Üniversitesi Ziya Gökalp Eğitim Fakültesi Dergisi, 17, 80-101.

*Altuntaş, í. ve Akyüz, E. (2015). Üçüncü ve dördüncü sınıf dinleme eğitiminde karşılaşılan güçlüklerin öğretmen görüşlerine göre belirlenmesi: nitel bir çalışma. International Journal of Language Academy, 3(3), 293-305.

Arslan, D. ve Bağcı, H. (2017). İlköğretim öğrencilerinin (2.-7. Sınıf) yazı hızı: kesit çalışması. Journal of International Social Research, 10(50), 451-462.

Arslan Özer, D. ve Bağcı, H. (2018). İlköğretim öğrencilerinin (2-7. Sınıf ) yazı okunaklılı̆ı. Uluslararası Türk Eğitim Bilimleri Dergisi, 11, 121-132.

*Ateş, S., Çetinkaya, C. ve Yıldırım, K. (2014). Elementary school classroom teachers' views on writing difficulties. International Online Journal of Educational Sciences, 6(2), 475-493.

Aydın, i. (2014). Türkçe öğretiminde yazılı anlatım çalışmalarındaki sorunlar üzerine bir inceleme. Karamanoğlu Mehmetbey Üniversitesi Sosyal ve Ekonomik Araştırmalar Dergisi, 4, 166-170.

*Babayiğit, Ö. (2019). İlkokul birinci sınıf öğrencilerinin dik temel yazı ile kelime yazım hatalarının incelenmesi. Erzincan Üniversitesi Eğitim Fakültesi Dergisi, 21(1), 230-246.

*Babayiğit, Ö. ve Ökten, B. (2016). Illkokul dördüncü sınıf öğrencilerinin dinlediğini anlama becerilerinin incelenmesi. International Journal of Education Technology and Scientific Researches, 1(1), 112.

Bağcı Ayrancı, B. (2016). Konuşma, konuşma eğitimi ve Türkçe programlarındaki yeri. Karaelmas Eğitim Bilimleri Dergisi, 4(1), 15-24.

Batdı, V. (2019). Meta-tematik analiz örnek uygulamalar. Ankara: Anı yayınları.

Batur, Z. ve Tufan, B. (2019). İlkokul öğrencilerinin serbest yazma etkinliklerindeki konu eğilimlerinin incelenmesi. Journal of History Culture and Art Research, 8(2), 372-389.

Bayat, S. (2015). illkokul birinci sınıf öğrencilerinin sesli okuma becerilerinin okula başlama yaşına göre değerlendirilmesi. KSBD Hüseyin Hüsnü Tekışık Özel Sayısı 1(7), 241-251.

Bayburtlu, Y. S. (2019). Öğrencilerin hazırlıksız konuşmalarında kelime hazinesi katsayılarının tespiti. Ana Dili Eğitimi Dergisi, 8(1), 44-66.

Belet, S. ve Yaşar, S. (2007). Öğrenme stratejilerinin okuduğunu anlama ve yazma becerileri ile türkçe dersine ilişkin tutumlara etkisi. Eğitimde Kuram ve Uygulama, 3(1), 69-86.

Bilge, H. ve Sağır, M. (2017). Ortaokul öğrencilerinin okuma hatalarının çeşitli değişkenlere göre incelenmesi. Ihlara Eğitim Araştırmaları Dergisi, 2(1), 77-88.

Bozkurt, B. Ü. (2016). Türkiye'de okuma eğitiminin karnesi: PISA ölçeğinden çıkarımlar. Abant izzet Baysal Üniversitesi Eğitim Fakültesi Dergisi, 16(4), 1673-1686.

Bozkurt, M. ve Memiş, A. (2013). Beşinci sınıf öğrencilerinin üstbilişsel okuduğunu anlama farkındalı̆̆ı ve okuma motivasyonları ile okuma düzeyleri arasındaki ilişki. Ahi Evran Üniversitesi Kırşehir Eğitim Fakültesi Dergisi, 14(3), 147-160.

Braze, D., Katz, L., Magnuson, J. S., Mencl, W. E., Tabor, W., Van Dyke, J. A. ve ark. (2016). Vocabulary does not complicate the simple view of reading. Reading and Writing, 29(3), 435-451.

Budinski, V. \& Lujić, I. (2018). Preschool teachers' opinions on the methodology of teaching activities for developing pre-reading and pre-writing skills. Croatian Journal of Education, 20(2), 131170.

*Bulut, P. ve Kuşdemir, Y. (2017). İlkokul öğrencilerinde görülen sesli okuma hatalarının öğretmen gözlemleri ışığında değerlendirilmesi. Okuma Yazma Eğitimi Araştırmaları, 5(1), 1-14.

Cemiloğlu, M. (2009). ilköğretim okullarında Türkçe öğretimi: Yeni programa uyarlanmış. Bursa: Alfa Aktüel Yayınları.

Ceren, D., Aydın, M. ve Onarıcıoğlu, A. S. (2018). Okuma eğitimi üzerine yapılan tezlerde eğilimler: bir içerik analizi çalışması. Kırşehir Eğitim Fakültesi Dergisi, 19(3), 2377-2392.

*Çakır, O., Aslantaş Arslan, G. ve Doğan, M.C. (2018). Illkokul öğretmenlerinin bitişik eğik yazı ve dik temel harflerin kullanımına ilişkin görüşlerinin değerlendirilmesi. Kastamonu Education Journal, 26(5), 1539-1550. 
Çalık, M. ve Sözbilir, M. (2014). İçerik analizinin parametreleri. Eğitim ve Bilim, 39(174), 33-38.

Çayci, B. ve Demir, M. K. (2006). Okuma ve anlama sorunu olan öğrenciler üzerine karşılaştırmalı bir çalışma. Journal of Turkish Educational Sciences, 4(4), 437-456.

Çeliktürk Sezgin, Z. ve Akyol, H. (2015). Okuma güçlüğü olan dördüncü sınıf öğrencisinin okuma becerilerinin geliştirilmesi. Turkish Journal of Education, 4(2), 4-16.

Çer, E. (2016). Türkçe öğretiminde etkinlikler. Ankara: Anı Yayıncılık.

Çetinkaya, F. Ç., Yıldırım, K. ve Ateş, S. (2017). İlkokul dördüncü sınıf öğrencilerinin okuduğunu anlama becerileri üzerinde konuşma ve okuma prozodisinin etkisi. Türkiye Sosyal Araştırmalar Dergisi, 21(2), 451-464.

Çiftçi, Ö. (2007). Aktif dinleme. Milli Eğitim Dergisi, 176(36), 231-242.

Delican, B. ve Temizyürek, F. (2016). Illkokul Türkçe ders kitaplarında yer alan metinlerin tür ve tema açısından incelenmesi. Bartın Üniversitesi Eğitim Fakültesi Dergisi, 5(3), 842-856.

Demir, C. (2018). Okullarımızda yazım eğitimi ve sorunları üzerine. Afyon Kocatepe Üniversitesi Sosyal Bilimler Dergisi, 20(3), 121-135.

*Demir, O. ve İzci, E. (2015). İlkokul (4. Sınıf) Türkçe dersi öğretiminde karşılaşılan sorunlar ve bu sorunların giderilmesine yönelik öğretmen görüşleri. Akademik Bakış Uluslararası Hakemli Sosyal Bilimler Dergisi, 49, 440-460.

Demir, T. (2010). Konuşma eğitiminde benmerkezci konuşmaya yönelik bir deneme. Kastamonu Eğitim Dergisi, 18(2), 415-430.

Dinçer, S. (2018). Eğitim bilimleri araştırmalarında içerik analizi: Meta-analiz, metasentez, betimsel içerik analizi. Bartın Üniversitesi Eğitim Fakültesi Dergisi, 7(1), 176-190.

Doğan, Y. ve Özçakmak, H. (2014). Dinleme becerisinin eğitimi üzerine yapılan lisansüstü tezlerin değerlendirilmesi. Ana Dili Eğitimi Dergisi, 2(2), 90-99.

Duran, E. ve Özdil, Ş . (2020). İlkokul dördüncü sınıf öğrencilerinin bilgilendirici metin yazma beceri düzeylerinin belirlenmesi. Okuma Yazma Eğitimi Araştırmaları, 8(1), 21-31.

Elma, C. ve Bütün, E. (2015). illkokul ve ortaokul öğrencilerinin yazılı anlatım becerilerine ilişkin öğretmen görüşleri. Abant izzet Baysal Üniversitesi Eğitim Fakültesi Dergisi, 15(2), 104-131.

Emiroğlu, S. ve Pınar, F. N. (2013). Dinleme becerisinin diğer beceri alanları ile ilişkisi. Turkish Studies, 8(4), 769-782.

Erden, G. ve Çelik, C. (2019). Sesli okuma becerisi ve okuduğunu anlama testinin psikometrik özelliklerinin incelenmesi: Geçerlik ve güvenirlik çalışması. Nesne Psikoloji Dergisi, 7(14), 118.

*Erdoğan, Ö., Gülay, A. ve Uzuner, F. G. (2017). Sınıf öğretmenlerinin yazma güçlüğüne ilişkin görüşleri. Electronic Journal of Social Sciences, 16(61), 700-718.

Feng, L., Lindner, A., Ji, X. R. \& Joshi, R. M. (2019). The roles of handwriting and keyboarding in writing: A meta-analytic review. Reading and Writing, 32(1), 33-63.

Finfgeld, D. L. (2003). Metasynthesis: The state of the art-so far. Qualitative Health Research, 13(7), 893-904.

Geva, E., Galili, K., Katzir, T. \& Shany, M. (2017). Learning novel words by ear or by eye? An advantage for lexical inferencing in listening versus reading narratives in fourth grade. Reading and Writing, 30(9), 1917-1944.

Girmen ,P., Kaya, M. F. ve Bayrak, E. (Mayıs, 2010). Türkçe eğitimi alanında yaşanan sorunların lisansüstü tezlere dayalı olarak belirlenmesi. 9. Ulusal Sınıf Öğretmenliği Eğitimi Sempozyumu, Elazığ.

Güneş, F. (2019). Türkçe öğretimi: Yaklaşımlar ve modeller. Pegem Akademi, Ankara.

Güneş, F. (2014). Konuşma öğretimi yaklaşım ve modelleri. Bartın Üniversitesi Eğitim Fakültesi Dergisi, 3(1), 1-27.

Güneş, F. (2013). Türkçe'de metin öğretimi yerine metinle öğrenme. Adıyaman Üniversitesi Sosyal Bilimler Enstitüsü Dergisi, 11, 603-637.

Hamzadayı, E. (2019). Yazılı anlatım biçimleri. N. Bayat (Ed.), Yazma ve eğitimi içinde (s. 249-274). Ankara: Anı Yayınları. 
İşci, C., Susar Kırmızı, F. ve Akkaya, N. (2020). Evaluation of creative writing products according to content and some variables. Elementary Education Online, 19(2), 718-732.

Katrancı, M. (2015). illkokul dördüncü sınıf öğrencilerinin kitap okuma motivasyonlarının incelenmesi. Ana Dili Eğitimi Dergisi, 3(2), 49-62.

Kim, Y. S. G., Park, C. \& Park, Y. (2015). Dimensions of discourse level oral language skills and their relation to reading comprehension and written composition: An exploratory study. Reading and Writing, 28(5), 633-654.

Kim, Y. S. G., Petscher, Y., Wanzek, J. \& Al Otaiba, S. (2018). Relations between reading and writing: A longitudinal examination from grades 3 to 6 . Reading and Writing, 31(7), 1591-1618.

Korhonen, A., Hakulinen-Viitanen, T., Jylhä, V. \& Holopainen, A. (2013). Meta-synthesis and evidencebased health care-a method for systematic review. Scandinavian journal of caring sciences, 27(4), 1027-1034.

*Kula, S., Budak, Y. ve Taşdemir, M. (2015). İlkokul 4. sınıf öğrencilerinin noktalama kurallarını öğrenme düzeyi. Uluslararası Avrasya Sosyal Bilimler Dergisi, 6(18), 58-80.

Kuru, O. ve Güneş, F. (2017). Akıcı konuşma problemi yaşayan ilkokul 4. sınıf öğrencilerinin konuşma becerilerinin geliştirilmesi. Erzincan Üniversitesi Eğitim Fakültesi Dergisi, 19(1), 33-47.

Kurudayıoğlu, M. ve Çetin, Ö. (2015). Temel beceriler ve Türkçe öğretimi. Ana Dili Eğitimi Dergisi, 3(3), 1-19.

Kuşdemir, Y. ve Katrancı, M. (2016). Okumada kaygı ve anlama: ana fikri bulamıyorum öğretmenim!. Eğitim ve Bilim, 41(183), 251-266.

Kuşdemir, Y., Katrancı, M. ve Arslan, F. (2018). Veli ve öğretmen gözüyle ilkokul öğrencilerinde yazı okunaklılığı. Ana Dili Eğitimi Dergisi, 6(2), 455-476

Kuzu, T. S. (2004). Etkileşimsel modele uygun okuma öğretiminin Türkçe bilgilendirici metinleri anlama düzeyine etkisi. Ankara Üniversitesi Eğitim Bilimleri Fakültesi Dergisi, 37(1), 55-77.

Landi, N. (2010). An examination of the relationship between reading comprehension, higher-level and lower-level reading sub-skills in adults. Reading and Writing, 23(6), 701-717.

Millî Eğitim Bakanlığı (2019). Türkçe dersi öğretim programı. Ankara: MEB Yayınları.

Millî Eğitim Bakanlığı (2018). Türkçe söz varlığı projesi. http://meb.gov.tr/turkce-soz-varligi-projesindeyeni-asama-26-ilden-1-milyon-ogrenci-veri-toplama-calismasina-katilacak/haber/21176/tr adresinden 05/09/2020 tarihinde alınmıştır.

*Önder, N. (2009). Illköğretim okulları 3. sınıf öğrencilerinin konuşma ve yazma sorunları (Bitlis örneği). Bolu: Abant İzzet Baysal Üniversitesi, Yayınlanmamış yüksek lisans tezi.

Örs, E. (2019). Bir ilkokul dördüncü sınıf öğrencisinin okuma-yazma öğrenimi üzerine durum çalışması. HAYEF Journal of Education, 16(1), 68-88.

Özbay, M. ve Çetin, D. (2011). Dinleme becerisinin geliştirilmesinde prozodik farkındalığın önemi. Muğla Üniversitesi Sosyal Bilimler Enstitüsü Dergisi, 26, 155-175.

Özbay, M. ve Melanlioğlu, D. (2012). Türkçe öğretim programlarının dinleme becerisi bakımından değerlendirilmesi. Electronic Turkish Studies, 7(1), 87-97.

Özbay, M. ve Melanlıoğlu, D. (2008). Türkçe eğitiminde kelime hazinesinin önemi. Yüzüncü Yıl Üniversitesi Eğitim Fakültesi Dergisi, 5(1), 30-45.

Paterson, B. L., Dubouloz, C. J., Chevrier, J., Ashe, B., King, J. \& Moldoveanu, M. (2009). Conducting qualitative metasynthesis research: Insights from a metasynthesis project. International Journal of Qualitative Methods, 8(3), 22-33.

Polat, S. (2015). The evaluation of qualitative studies in turkey about critical thinking skills: A metasynthesis study. International Online Journal of Educational Sciences, 7(3), 229-243.

Polat, S. ve Ay, O. (2016). Meta-sentez: Kavramsal bir çözümleme. Eğitimde Nitel Araştırmalar Dergisi, 4(2), 52-64.

Puliatte, A. \& Ehri, L. C. (2018). Do 2nd and 3rd grade teachers' linguistic knowledge and instructional practices predict spelling gains in weaker spellers?, Reading and Writing, 31(2), 239-266.

*Sarikaya, I. ve Sökmen, Y. (2019). Illkokul öğrencileri yazmayı neden zor ve sıkıcı bir etkinlik olarak nitelendiriyor? Sınıf öğretmenlerinin görüşleri. B. Duman (Ed.), 2. Ulus/ararası Temel Eğitim Kongresi Kitabı (ss. 568-574). Muğla: Muğla Sıtkı Koçman Üniversitesi Eğitim Fakültesi. 
Seçkin Yılmaz, Ş. ve Baydık, B. (2020). Comparison of language skills of students with and without reading difficulties. Elementary Education Online, 19(2), 782-802.

Seçkin Yılmaz, Ş. ve Baydık, B. (2017). Okuma performası düşük olan ve olmayan ilkokul öğrencilerinin okuma akıcılıkları. Ilkögretim Online, 16(4), 1652-1671.

Semeraro, C., Coppola, G., Cassibba, R. \& Lucangeli, D. (2019). Teaching of cursive writing in the first year of primary school: Effect on reading and writing skills. PloS one, 14(2), 1-17.

Sönmez, H. (2020). Öğretmen adaylarının okuma güç stratejilerini kullanmalarına ilişkin bir inceleme. Avrasya Sosyal ve Ekonomi Araştırmaları Dergisi, 7(3), 1-18.

Spataro, S. E. \& Bloch, J. (2018). "Can you repeat that?" Teaching active listening in management education. Journal of Management Education, 42(2), 168-198.

Spycher, P., Austin, K. \& Fabian, T. (2018). The writing-centered classroom. Educational Leadership, 75(7), 54-59.

Şahbaz, N. K. ve Çekici, Y. E. (2012). Disiplinler arası bir disiplin olarak Türkçe eğitimi. Electronic Turkish Studies, 7(3), 2367-2388.

Şahin, N. (2019). Ortaokul öğrencilerinin okuma tutumları ve okuma motivasyonları arasındaki ilişkinin incelenmesi. Ana Dili Eğitimi Dergisi, 7(4), 914-940.

Şahin, A. (2012). Illköğretim 4 ve 5. Sınıf öğrencilerinin kitap okuma alışkanlıklarının sosyo-ekonomik düzeylerine göre incelenmesi. Journal of Turkish Educational Sciences, 10(2), 367-388.

Tağa, T. ve Ünlü, S. (2013). Yazma eğitiminde karşılaşılan sorunlar üzerine bir inceleme. Electronic Turkish Studies, 8(8), 1285-1299.

Tavşanlı, Ö. F. ve Kaldırım, A. (2018). Illkokul 2. sınıf öğrencilerinin süreç temelli yazma uygulamalarına ilişkin görüşlerinin incelenmesi. Ana Dili Eğitimi Dergisi, 6(3), 859-876.

Temel, S. ve Katrancı, M. (2019). Illkokul öğrencilerinin yazılı anlatım becerileri, yazmaya yönelik tutumları ve yazma kaygıları arasındaki ilişki. Avrasya Uluslararası Araştırmalar Dergisi, 7(17), 322-356.

Temizyürek F., Erdem i. ve Temizkan M. (2017). Konuşma eğitimi: Sözlü anlatım. Ankara: Pegem Akademi Yayıncılık.

Tok, R. ve Erdoğan, Ö. (2017). İlkokul 2. 3. ve 4. sınıf öğrencilerinin yazma becerilerinin incelenmesi. Yüzüncü Yıl Üniversitesi Eğitim Fakültesi Dergisi, 14(1), 1003-1024.

*Tok, M. ve Ünlü, S. (2014). Becerisi sorunlarının ilkokul, ortaokul ve lise öğretmenlerinin görüşleri doğrultusunda karşılaştırılmalı olarak değerlendirilmesi. Elektronik Sosyal Bilimler Dergisi, 13(50), 73-95.

Uçgun, D. (2007). Konuşma eğitimini etkileyen faktörler. Sosyal Bilimler Enstitüsü Dergisi, 22(1), 59-67.

*Ulu, H. (2019). Illkokul birinci sınıf öğrencilerinin dik temel yazılarının okunaklılık ve yazım hataları açısından incelenmesi. Uluslararası Alan Eğitimi Dergisi, 5(2), 195-211.

Ulu, H. (2018). İlkokul dördüncü sınıf öğrencilerinin yazma eğilimleri, tutumları ile yazma başarıları arasındaki ilişki. Kastamonu Education Journal, 26(5), 1601-1611.

*Uygun, M. ve Katrancı, M. (2013). Sınıf öğretmenlerinin Türkçe derslerinde karşılaştıkları sorunlara ilişkin görüşleri. Çankırı Karatekin Üniversitesi Sosyal Bilimler Enstitüsü Dergisi, 4(1), 255-270.

Uzunkol, E. (2013). Akıcı okuma sürecinde karşılaşılan sorunların tespiti ve giderilmesine yönelik bir durum çalışması. Mersin Üniversitesi Eğitim Fakültesi Dergisi, 9(1), 70-83.

Vandergrift, L. (2004). Lıstenıng to learn or learnıng to lısten?. Annual Review of Applied Linguistics, 24, 3-25.

*Yağcl, E., Katrancı, M., Erdoğan, Ö. ve Uygun, M. (2014). Sınıf öğretmenlerinin kelime öğretiminde karşılaştıkları sorunlar ve kullandıkları yöntem-teknikler. International Journal of Curriculum and Instructional Studies, 2(4), 1-12.

*Yalar, T. (2010). Illköğretim 3. sınıflarda Türkçe dersi öğretiminde karşılaşılan sorunların öğretmen görüşlerine göre belirlenmesi. Dicle Üniversitesi Ziya Gökalp Eğitim Fakültesi Dergisi, 15, 30 41.

Yamaç, A. ve Çeliktürk Sezgin, Z. (2018). İlkokul dördüncü sınıf öğrencilerinin okuma kaygıları, akıcılıkları, motivasyonları ve okuduğunu anlamaları arasındaki ilişkiler. Eğitim ve Bilim, 43(194), 225-243. 
Yıldırım, K. ve Ateş, S. (2010). Sınıf öğretmenlerinin bitişik eğik yazı öğretim uygulamalarına ilişkin görüşleri. Pamukkale Üniversitesi Sosyal Bilimler Enstitüsü Dergisi, 5, 57-71.

Yıldız, M. (2013). Illköğretim 3, 4 ve 5. sınıf öğrencilerinin okuma motivasyonlarının incelenmesi. Eğitim ve Bilim, 38(168), 260-271.

Yıldız, E., Alaçam Akşit, A. C. ve Uyar, S. (2016). illkokul 4. sınıf öğrencilerinin dinleme sürecine ilişkin görüş ve algıları. Journal of International Social Research, 9(45), 911-924.

Yıldız, M. ve Akyol, H. (2011). İlköğretim 5. sınıf öğrencilerinin okuduğunu anlama, okuma motivasyonu ve okuma alışkanlıkları arasındaki ilişki. Gazi Üniversitesi Gazi Eğitim Fakültesi Dergisi, 31(3), 793-815.

Yıldız, M. ve Kaman, Ş. (2016). İlköğretim (2-6. Sınıf) öğrencilerinin okuma ve yazma tutumlarının incelenmesi. Türkiye Sosyal Araştırmalar Dergisi, 20(2), 507-522.

Yıldız, M., Yıldırım, K. ve Ateş, S. (2009). Sınıf öğretmenlerinin sınıf tahtasına yazdıkları yazıların okunaklılık bakımından öğrencilere model olmadaki uygunluğu. Uluslararası Insan Bilimleri Dergisi, 8(2), 75-88.

Yılmaz, M. (2008). Kelime tekrar tekniğinin akıcı okuma becerilerini geliştirmeye etkisi. Türk Eğitim Bilimleri Dergisi, 6(2), 323-350.

\section{Introduction}

\section{Extended Abstract}

This study aimed to evaluate the findings of studies determining the problems encountered in Turkish lessons at primary school level by reinterpreting and comparing them. This approach will ensure that the findings of studies conducted in different places and with different sample groups for the same purpose are presented with a holistic approach. Thus, classroom teachers will have the opportunity to see the problems encountered in Turkish lessons from a broad perspective. The study aimed to draw attention to the fact that studies for primary school students in the field of Turkish teaching should be structured separately from studies for students at other levels by focusing the research on the problems encountered in Turkish lessons only at the primary school level. In addition, this study also enabled researchers who are interested in the subject to see the areas in which the studies regarding the issue are concentrated and those in which they are found lacking. In line with this general purpose, this study aimed to reveal the problems encountered in listening, speaking, reading and writing skills in Turkish lessons at primary school level.

\section{Method}

The meta-synthesis method, which is one of the content analysis methods, was applied in this study. In this method, findings of studies on the same subject are discussed and evaluated with a critical understanding. The purpose of meta-synthesis research is to produce more holistic and functional interpretations based on individual studies. In this study, the findings of the studies conducted to determine the problems encountered in Turkish lessons at primary school level were interpreted, compared, and evaluated.

In the study, first of all the research questions were prepared, then the concepts of "Turkish, listening, speaking, reading, and writing" were searched for in the databases of Google Academic, CoHE Academic and the CoHE Thesis Center, and no restrictions were made in terms of the publication year of the research. The studies to be included in the study were determined by examining the title, abstract, method and study groups of the studies found as a result of the search. This study was limited to the studies focusing on the problems encountered in Turkish lessons at the primary school level. 17 studies meeting these criteria were determined, and the findings of the studies were classified according to the themes (listening, speaking, reading and writing skills in Turkish lessons) and related sub-themes.

\section{Results and Discussion}

The findings of the study showed that there were five studies, two of them directly, aiming to determine the problems that primary school students encounter in listening skills. In addition to being 
a skill in itself, listening forms the basis for the acquisition and development of other skills by involving various mental processes such as analysis, synthesis, association, and questioning; therefore, listening skills must be examined more. For this reason, taking the relationship between listening skills and other skills into account, individual studies can be carried out for listening skills and the dimensions and development of listening can be revealed more clearly. The findings of the study showed that students' lack of attention and motivation, and also their lack of vocabulary were the main reasons affecting listening skills negatively. Therefore, it is important that teachers conduct activities aimed at increasing students' attention and motivation and enriching their vocabulary. In addition, the richness of students' vocabulary will influence their understanding of listening products positively. Thus, this situation will enhance students' attention and motivation positively and enable them to benefit more from learning and teaching processes.

The findings of this study revealed that there were totally four studies, one of them directly, addressing the problems students encounter in speaking skills. In these studies, it was stated that the majority of the problems encountered by students in speaking skills were due to the lack of vocabulary. The development of individuals' vocabulary, defined as the accumulation of words stored in individuals' memories as a result of their learning experiences, can be supported most effectively by Turkish lessons. For this reason, activities aimed at improving the vocabulary of students are required so that they will be able to speak fluently.

The findings of this study showed that text-related problems prevented the development of students' speaking skills. The texts in Turkish course books have been used in teaching language skills for a long time. Students are expected to make gains through the activities given after these texts. Therefore, the quality of the texts and activities will enable the efficient use of time allocated for learning processes and the students will make gains in a shorter time.

It was seen that the problems that students encountered in reading skills were mainly related to reading errors, fluency, and reading comprehension. The concepts of reading fluency and reading comprehension are related to each other, and fluent text reading is defined as reading that enables the most accurate comprehension. In order to improve students' reading fluency and reading comprehension skills, word recognition and vocabulary improvement activities should be carried out by teachers. Inadequate reading motivation was not reported as a problem in previous studies. This may be due to the fact that the participants of the studies focused more on students' reading errors, since reading errors are a more concrete and observable situation than the concept of motivation. This situation should not cause teachers to ignore the lack of motivation, which is an underlying reason for reading problems. Especially in primary school, which is a critical period for acquiring reading habits, teachers' planning of activities to increase students' reading motivation will enable other reading problems to be eliminated.

It was observed that problems regarding students' writing skills were mostly related to using punctuation marks, applying spelling rules, legibility of writing and the physical dimension of writing. The fact that students have different characteristics in terms of writing skills makes the situation difficult for teachers. Therefore, it can be concluded that students should be monitored individually and continuously to enable them to write legibly. Another important result of the study regarding writing skills was that teachers' incorrect attitudes and behaviors affected students' writing skills negatively. Due to the fact that teachers did not include writing activities in their classes, students' legible writing skills were adversely affected. For this reason, periodic in-service training of teachers regarding writing skills will be beneficial in terms of reducing teacher-related problems. In order to avoid the existence of a neglected skill among all language skills, it is recommended that researchers focus on the needs of primary school students and conduct studies aiming to improve their vocabulary. 